DOI https://doi.org/10.18551/rjoas.2018-12.05

\title{
THE INFLUENCE OF HUMAN RESOURCE COMPETENCE AND ORGANIZATIONAL CULTURE TO THE PUBLIC SERVICE PERFORMANCE (E-LAMPID) IN THE URBAN VILLAGE EMPLOYEE, MULYOREJO, SURABAYA
}

\author{
Indriani Hilda Lussi \\ Magister Program of Human Resource Development, University of Airlangga, Indonesia \\ E-mail: hildaluissi@gmail.com
}

\begin{abstract}
Public services is all forms of service both in the form of goods or services that provided by the government to meet a public need. Public services that provided by government is many kind, one of them are population administration. Department of Population and Civil Registration Surabaya is one of agency that gives service about population administration, but in their practice still found problems and obstacles. Therefore, the Surabaya city government makes an innovation, which is e-lampid. E-lampid is online services to birth certificate, death sertificate, and the move out license. E-lampid spread to the all village office in Surabaya to ease range community, one of them is sub district of Mulyoredjo.The purpose of this research is to analyze the influence of human resource competence and organizational culture to the public service performance (E-lampid) in the urban village employee, Mulyorejo Surabaya. Public Satisfaction index of general services in Surabaya city on 2016, Mulyorejo was in worst category. it certainly cannot be separated from HR competencies and organizational culture of the employee in the organization.
\end{abstract}

\section{KEY WORDS}

Human resource, competence, organizational culture, public service performance, employee.

Surabaya City Government continues innovate to improve services to the community. Governments' city of Surabaya is constantly working to develop smart city by using the egovernment system that aims to provide a better service to the people of the city of Surabaya. By developing applications for e-lampid. E-lampid is short for electronic born dead move came a settlement integrated information systems are built and developed by the Government of the city of Surabaya in order to facilitate the community in the management of the Administration the residency. Some settlement services that can be managed online via e-lampid i.e. a birth certificate, death certificate, certificate moved-come, as well as the affidavits move-out. The application of e-lampid is an idea of the population and the civil registry Agency of the city of Surabaya in support of organizing good governance in an environment of the Surabaya City Government.

The main problem underlying the emergence of initiatives e-Lampid application is the volume of the line management of the birth and death certificate in the service of the population and civil registration are always solid every weekday. There are about 400 of the petition. While processing the file previously pegged seven working days. It encourages the Government of the city of Surabaya to replace manual service system with information technology-based service system (online). The goal, giving the ease, effectiveness, and efficiency for the community. The chains of bureaucracy trimmed so it can all be managed online. Moreover, the current e-Kios devices that can access the application of e-Lampid are available in every Village and Sub district.

Based on a phenomenon occur in Mulyorejo and based on the observation of the researcher supported by the result of employees' performance evaluation show that, there are a lot of employees who know little about main duties and function to do, lack of skills and experience in accomplishing their work, and have low work control attitude in handling certain job which becomes their main duties and function. It is likely to happen because some of the employees have low competence in doing activities so that the result cannot be achieved optimally. In doing main duties and function, the government employees 
of mulyorejo have not fulfilled the expectation although the target of the performance tends to increase every year. In fact, the result obtained has not been maximally achieved yet. In this case, the phenomenon relates to the competence and organizational culture. However, the reality shows that some of the employees seem to lack of innovation in accomplishing every job given to them and lack of attention on working carefully and in detail so that some mistakes relating to the accomplished work occur.

The fact that man is a decisive factor in the successful operation of any organization need not be questioned. Any high performing organization is linked with high performing people. Selecting talented employees - (high potentials and high performers) who are able to carry out the organization's vision, mission and meet the targets is critical for the organization as well as the organization's ability to create supportive culture for these people. The question remains what gives humans the opportunity to successfully maintain its position in the company? Do we talk about the skills, knowledge, ability, talent, employee engagement? This human quality is called competence. Understanding of the concept of competency and competence is very wide. It implies concepts such as ability, behavior, activity, or even complex of operations. These components should then be reflected in above-average performance of man in a organization.

In 1973 David McClelland, working in the educational field in US, published a study Testing for Competencerather than for Intelligence, where personal competencies (defined as motives and personality traits) or individualcharacteristics, were recognized as significant predictors of employee performance and success. His work wasprovocative, because he argued the personal competencies are more important in predicting occupational success than traditional psychometrics such as IQ and aptitude tests. McClelland is often credited with launching the competency theory in HR management. Boyatzis (1982) defined a competency as "an underlying characteristic of a person which resulted in effective and/or superior performance in a job." According to Boyatzis, a competency in a job represented great ability and high performance. Boyatzis diagnosed problem raised by human resource managers. They needed to find a single and meaningful vocabulary for human resource department anywhere in the world - in the US, Latin America and Europe, allowing them to distinguish average performers from above average performers. Professor Harold $M$. Schroder from Princeton University, author of Managerial Competence - The Key to Excellence (1989) defined 11 key managerial competencies that incorporate into the four basic areas: cognitive competencies, motivational competence, directional competence, performance competencies. White (1959) defined competence as designate skills developed by self-organization and required for the performance. This first era of competencies in HR management was typical for observing of individual competencies (White - 1959; McClelland - 1973; Boyatzis-1982; Schroder-1989; Woodruffe 1992; Spencer-Spencer-1993). The second phase of competencies in HR management is typical by creation and managing of competency models in organizations. (Mansfield-1996; McLagan-1997; Lucia-Lepsinger1999; Rothwell-Lindholm, 1999). Prahalad and Hamel (1989) advanced the idea of core competencies and here we talk about the third phase of competencies in HR management. This phase is based on identification of core competencies needed to gain a competitive advantage (Prahalad-Hamel- 1989; Ulrich-Lake- 1991; Rothwell-Lindholm- 1999; DelamareWintertone- 2005). Based on this definition, we can talk about the potential (non-observable) competencies and the (observable) activities performing the competence. Activities can be observed and measured.

Follet (2004) states that human resource competence is a developing model of human potential quality. It means that to achieve the individual or organizational goals, human resources should always do their duties based on beneficial value and advantage of activities they do. Then, from this statement, Follet theory about potential competence of human resources was born. In addition, theory proposed by Donald (2007) states that basically, the self-development access is basically an introduction of human resource competence which introduces Window Theory stating that each self-development owned by human can be observed through four perspectives which is like a window i.e. knowledge, skills, experience, and attitude. 
According to Robbins (2007), the strong culture has stronger impact on the values in an organization because organizational culture has internal climate, and with high intensity, it can construct behavior in the organization which can affect someone's creativity. The organizational culture is an attitude and work behavior based on the employees' characteristic with some indicators i.e. innovation, attention to any details, team-oriented, and aggressiveness.

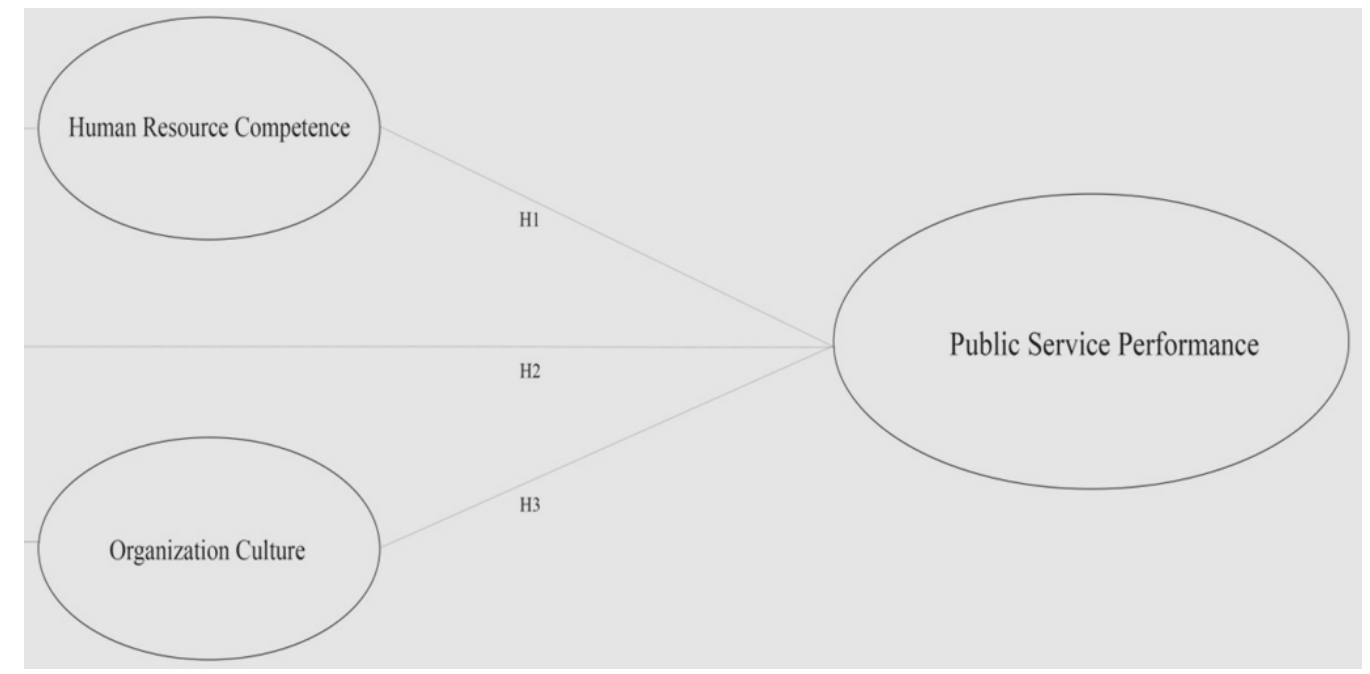

Figure 1 - Conceptual Framework

Hypothesis:

$\mathrm{H} 1$ : Human resource competence had significant influence to the public service performance;

$\mathrm{H} 2$ : Organizational culture had significant influence to the public service performance;

H3: Human resource competence and organizational culture had significant influence to the public service performance.

\section{METHODS OF RESEARCH}

The study used a quantitative research method since the purpose is to explain the correlation among variables Human Resource Competence, organizational culture to the Public service performance. The method of data analysis in this research is descriptive data analysis, which has a goal to show the data image collected from the research locations. The analysis technique that is used is the path analysis with SPSS applications.

The location of the research at 6 urban village of Mulyorejo, Surabaya. The population was about 81 respondents. This study used a questionnaire distributed to 81 respondents on 6 urban village of Mulyorejo, Surabaya. Assumptions underlying the Path analysis is to use the test for normality and linearitytest. Here are the results of normality test and linearity test: The normality assumption is based on the significance of the test Kolmogorov-Smirnov, the human resource Competency variables (X1), variable organizational culture $(X 2)$ and the Performance of public service variable $(\mathrm{Y})$ is more than the value of 0.05 means that human resources Competency variables (X1), variables of organizational culture (X2) and the Performance of public service variable $(\mathrm{Y})$ follow a normal distribution, the value of Asymp. SIG generated amounted to 0.20 exceeding 5\% (0.05), the Gaussian itself.

Multicollinearity test is meant to be more aware of the relationship between the variables used in the regression models. Ghozali, Imam. (2013; 301) mentions the figure of tolerance to avoid symptoms of VIF multicollinearity is less than 10. As for the value of the variable is generated by the VIF Competence human resources (X 1) and variable organizational culture $(X 2)$ are based on the table above, it appears that between free variables does not occur multicollinearity, judging from the value of the variable on the VIF 
Competence human resources $(X 1)$ of 1.578 less than 10 and Variable organizational culture (X 2) of 1.578 numbers less than 10.

Table 1 - One-Sample Kolmogorov-Smirnov Test

\begin{tabular}{|ll|r|}
\hline & & $\begin{array}{r}\text { Unstandardiz } \\
\text { ed Residual }\end{array}$ \\
\hline $\mathrm{N}$ & & 81 \\
Normal Parameters & Mean & .0000000 \\
Most Extreme Differences & Std. Deviation & 1.61692462 \\
& Absolute & .086 \\
& Positive & .086 \\
Test Statistic & Negative & -.057 \\
Asymp. Sig. (2-tailed) & & .086 \\
\hline
\end{tabular}

Coefficients $^{\mathrm{a}}$

\begin{tabular}{|c|c|c|c|c|c|c|c|c|c|c|c|}
\hline \multirow[b]{2}{*}{ Model } & & \multicolumn{2}{|c|}{ Unstandardized Coefficients } & \multirow{2}{*}{$\begin{array}{c}\begin{array}{c}\text { Standardized } \\
\text { Coefficients }\end{array} \\
\text { Beta }\end{array}$} & \multirow[b]{2}{*}{$t$} & \multirow[b]{2}{*}{ Sig. } & \multicolumn{3}{|c|}{ Correlations } & \multicolumn{2}{|c|}{ Collinearity Statistics } \\
\hline & & $B$ & Std. Error & & & & Zero-order & Partial & Part & Tolerance & VIF \\
\hline \multirow[t]{3}{*}{1} & (Constant) & 5.317 & 1.394 & & 3.815 & .000 & & & & & \\
\hline & $\begin{array}{l}\text { Kompetensi Sumber } \\
\text { Daya Manusia }\left(X_{1}\right)\end{array}$ & .392 & .030 & .713 & 12.925 & .000 & .891 & .826 & .567 & .634 & 1.578 \\
\hline & Budaya Organisasi $(X 2)$ & .273 & .051 & .295 & 5.352 & .000 & .726 & .518 & .235 & .634 & 1.578 \\
\hline
\end{tabular}

a. Dependent Variable: Kinerja Pelayanan Publik $(Y)$

\section{RESULTS AND DISCUSION}

T-test was conducted to see whether each independent variable: HR competencies (X1) and organizational culture (X2) influential partially or singly against the public service performance variables $(\mathrm{Y})$. As for the results of the $\mathrm{T}$ - test is as follows:

Table 2 - T-test

\begin{tabular}{|c|c|}
\hline X variable & t-value \\
\hline HR competence (X1) & 12,925 \\
Organizational culture (X2) & 0,000 \\
0,352 & 0,000 \\
\hline
\end{tabular}

ANOVA $^{a}$

\begin{tabular}{|c|c|c|c|c|c|c|}
\hline & & $\begin{array}{l}\text { Sum of } \\
\text { Squares }\end{array}$ & df & Mean Square & $\mathrm{F}$ & Sig. \\
\hline \multirow[t]{3}{*}{1} & Regression & 1182.276 & 2 & 591.138 & 220.452 & $.000^{b}$ \\
\hline & Residual & 209.156 & 78 & 2.681 & & \\
\hline & Total & 1391.432 & 80 & & & \\
\hline
\end{tabular}

a. Dependent Variable: Kinerja Pelayanan Publik ( $)$

b. Predictors: (Constant), Budaya Organisasi $(X 2)$, Kompetensi Sumber Daya Manusia (X1)

Based on the test result, the significant result of independent variable are less than $5 \%$ or under $(0,05)$ can thus be inferred that the HR competence (X1) and Organizational culture (X2) partially has significant effect to public service Performance Variables (Y).

$F$ test results can be used to find out the influence of human resources Competency $(X$ 1) and Variable organizational culture $(X 2)$ to public service Performance Variables $(Y)$.

Based on the table above shows that the value of the count of $220.452 \mathrm{~F}$ with a level significantly less than $5 \%$ (sig. 0.05 ) of 0.000 . This means human resources Competency variables $(X \quad 1)$ and organizational culture variable (X 2) simultaneously has significantly effect to public service Performance Variables $(Y)$.

\section{CONCLUSION AND SUGGESTIONS}

Based on the findings and discussion, the study can conclude the following points: the HR competence is the dimension of the Act of duties, where such action is used by the 
employees to accomplish their work satisfactorily and the employee what is given in the form of different levels of performance. This limitation means that there is an implicit connection between the HR competencies with performance. Based on the findings of the study, the HR competence of the urban village employee in Mulyorejo has significant influence toward public service performance.

Organizational culture is able to arouse employee performance against the organization. Organizational culture is one of the factors needed to improve the performance of employees, as long as the employees still feel happy with a culture that is applied and it is believed by the Organization, then the employee's performance against the Organization, will still be able to perceived and the opportunities for the achievement of the Organization's success. Based on the findings of the study, the organizational culture of the urban village employee in Mulyorejo has significant influence toward public service performance.

According to the conclusion, several suggestions can be made as follows: employee Performance Appraisal should be an effort to encourage or enhance the competence of employees, future researches should expand the subject of the study and also analyze another variable to expect that analyzing another variable will be better represent the future need of public performance.

\section{REFERENCES}

1. Boyatzis, R. E.(1982).The Competent Manager: A Model for Effective Performance. New York: John Villey \& Sons.

2. Boyatzis, R. E. (2008). Competencies in the 21st Century. Journal of Management Development, 27 (1), 5-1

3. Delamare Le Deist, F. \& Wintertone, J. (2005). What Is Competence? Human Resource Development International, 8 (1), 27-46.

4. McClelland, D. C. (1973). Testing for Competence Rather Than for Intelligence. American Psychologist, 28, 1-14

5. Follet, M. (2004). Human Resources Management in quality and quatity.

6. Donald, M.T. (2007), Competence of Personal in Prospective. Theories.

7. Robbins, S.P. (2007). Perilaku Organisasi. Jakarta: Salemba Empat. 